\title{
Isolation and Identification of Novel Estrogenic Compounds in Yam Tuber (Dioscorea alata Cv. Tainung No. 2)
}

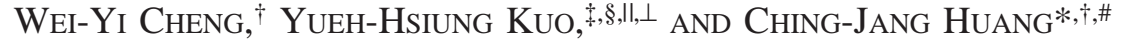

\begin{abstract}
Division of Nutritional Biochemistry, Institute of Microbiology and Biochemistry, Department of Biochemical Science and Technology, and Department of Chemistry, National Taiwan University, Taipei, Taiwan, College of Pharmacy, China Medical University, Taichung, Taiwan, and Agricultural Biotechnology Research Center, Academia Sinica, Taipei, Taiwan
\end{abstract}

\begin{abstract}
Yam (Dioscorea spp.) is a common food in tropical areas and has been shown to improve the status of sex hormone in postmenopausal women. In this study, the estrogenic activity of yam was examined and active compounds were isolated and identified based on ligand-dependent transcriptional activation through estrogen receptors. Ethyl acetate extracts of various species/varieties of yam were found to activate estrogen receptors $\alpha$ and $\beta$ to various extents. The extract of Dioscorea alata cv. Tainung No. 2 tuber was fractionated by repeated silica gel column chromatography. The active compounds were isolated and purified by preparative HPLC. Based on NMR and mass spectrometry, two new compounds, hydro- $Q_{9}$ chromene (1) and $\gamma$-tocopherol-9 (2), together with three known compounds, $R R R$ - $\alpha$-tocopherol (3), coenzyme $Q_{9}(4)$, and 1-feruloylglycerol (5), were identified and shown to activate human $\mathrm{ER} \alpha$ and $\beta$. These results provide basic evidence for the beneficial effect of yam for menopausal women.
\end{abstract}

KEYWORDS: Discorea alata; phytoestrogen; chromanol; coenzyme Q9; 1-feruloylglycerol; chromenol

\section{INTRODUCTION}

Yam is the common name for rhizomes of plants from the genus Dioscorea. There are over 600 species of Dioscorea in the world, 12 of which are edible and widely used as staple medicinal food (1). In Taiwan, five major species, $D$. alata, $D$. batatas, D. japonica, D. alata L. var purpurea, and $D$. doryophora (2), are cultivated and consumed as a food with tonic function. Tainung No. 2 (D. alata) is one of the most popular varieties of yams developed by the Taiwan Agricultural Research Institute (TARI) for high yield commercial production in 1996.

Yams have been implicated in the promotion of the health of postmenopausal women (3). Wild Mexican yam has been marketed for treating hot flashes, irritability, depression, and insomnia, despite the efficacy being unknown (4). Wu et al. (5) demonstrated that replacing two-thirds of staple food with yam in postmenopausal women for 30 days improved the status of sex hormones, lipids, and antioxidants that might reduce the risk of breast cancer and cardiovascular diseases. Despite the implication that yam might contain phytoestrogens, the estro-

* Corresponding author. Tel: +886-2-33662276. Fax: +886-2-23621301. E-mail: cjjhuang@ntu.edu.tw.

$\dagger$ Division of Nutritional Biochemistry, Institute of Microbiology and Biochemistry, National Taiwan University.

$\doteqdot$ Department of Chemistry, National Taiwan University.

$\S$ China Medical University.

"Academia Sinica.

${ }^{\perp}$ Equal contribution with corresponding author

\# Department of Biochemical Science and Technology, National Taiwan University. genic activity of yam has never been reported and active compounds are unknown.

Phytoestrogens are plant-derived compounds that can interact with estrogen receptors (ER) and exhibit estrogenic/antiestrogenic activities (6). As a member of steroid nuclear receptor superfamily, ER is a ligand-dependent transcription factor. It mediates the function of estrogen by binding to specific ligands and activating the transcription of specific target genes. There are two types of estrogen receptors in human, hER $\alpha$ (NR3A1) and $\mathrm{hER} \beta$ (NR3A2), with distinct tissue distribution. $\mathrm{hER} \alpha$ and $\mathrm{hER} \beta$ share $97 \%$ homology in the DNA binding domain and $59 \%$ homology in the ligand binding domain (7), indicating similar but not identical ligand binding properties. Some phytoestrogens, for example, genistein, daidzein, and coumestrol, can bind to ER and have higher affinity for $\mathrm{ER} \beta$ than for ER $\alpha$ (6). These are considered "natural" selective estrogen receptor modulators (SERMs) and may play protective roles in cancer, inflammation, heart disease $(8,9)$, and osteoporosis $(10,11)$.

To examine the estrogenic activity and active compounds in yam, we constructed vectors containing cDNA of GAL4-hER $\alpha$ and GAL4-hER $\beta$ ligand binding domain (LBD) chimeric receptors and established a transactivation assay that can measure the ligand-dependent transcriptional activation of reporter gene through $\operatorname{hER} \alpha$ or $\operatorname{hER} \beta$ (12). Seven species/ varieties of Taiwanese yam were then extracted and tested for estrogenic activity. Activators of $\mathrm{hER} \alpha$ and $\mathrm{hER} \beta$ were detected in ethyl acetate extract of all seven species/varieties of yam. Five active compounds in D. alata tubers (Tainung No. 2) were then isolated and identified. 


\section{MATERIALS AND METHODS}

Materials. For testing estrogenic activity, lyophilized powders of seven species/varieties (70W20, 70W34, 70W59, 90W01, 90DN01, 83CM121, and TNG2) of yam were provided by Dr. S. Y. Liu, Department of Agronomy, Laboratory of Plant Germplasm, Taiwan Agricultural Research Institute. 70W34, 83CM121, and TNG2 are different varieties of the $D$. alata $\mathrm{L}$ species. The remaining four species are D. doryophora, D. persimilis, D. nipponica, and D. batatas. For isolation of active compounds, $D$. alata tubers (Tainung No. 2, TNG2) were purchased from Ming-Jian Farmers' Association, Nantou County, Taiwan. The whole yam tubers were peeled, sliced, lyophilized, and ground to powder.

Transactivation Assay for Estrogenic Activity. In the transactivation assay, vectors containing GAL4hER $\alpha$ (or $\beta$ ) LBD (ligand binding domain) chimeric receptors and the (UAS) $)_{4}$-alkaline phosphatase reporter genes were cotransfected into $\mathrm{CHO}-\mathrm{K} 1$ cells. Treatment of cotransfected cells with samples containing active compounds that can bind to ER LBD will then trigger the binding of GAL4 to the UAS sequence upstream of the reporter gene and activate the transcription of the reporter gene, i.e., the secreted form of the human placental alkaline phosphatase (SEAP). By measuring the alkaline phosphatase activity, the estrogen activity can then be determined.

The transactivation assay for estrogen receptors used in this study was modified from that for peroxisome proliferator activated receptor used in our laboratory (13). Vectors containing chimeric receptor constructs used were $\mathrm{pBK}-\mathrm{CMV}-\mathrm{Gal} 4-\mathrm{hER} \alpha$-ligand-binding domain (Gal4-hER $\alpha \mathrm{LBD})$ and the pBK-CMV-Gal4-hER $\beta$ - ligand-binding domain (Gal4-hER $\beta$ LBD), respectively. LBD (833-1785 bp) of hER $\alpha$ was cloned by RT-PCR. Total RNA was extracted from a surgically excised human uterus tissue, reverse-transcribed to cDNA, and used as the template. Primers used were 5-GGAATTCCGTGAAGTGGGGTCTGC-3 (forward) and 5-TGGGCCCATCAGACTGTGGCAGGG-3 (reverse). Full-length $\mathrm{hER} \beta$ cDNA was a kind gift from Dr. J. A. Gustaffson, Department of Medical Nutrition, Karolinska Institute, Huddinge. The LBD (721-1593 bp) was cloned by PCR. Primers used were 5-AAGCTTTGTGCCGGCAAGGCCA-3 (forward) and 5-TCTAGATCACTGAGACTGTGGG-3 (reverse). The LBDs of $\mathrm{hER} \alpha$ and $\mathrm{hER} \beta$ were excised, ligated to $\mathrm{pBKCMV}$ containing GAL4. The correct in-frame fusions were confirmed by sequencing. The vector containing the reporter gene, pBK-CMV-(UAS) ${ }_{4}$-tk-alkaline phosphatase (AP), was also kindly provided by Dr. J. A. Gustaffson. These vectors were transformed into Escherichia coli (XL1-Blue) and extracted by QIAGEN Plasmid Midi Kits after cultivation.

CHO-K1 cells (American Type Culture Collection, Rockville, MD) were grown at $37{ }^{\circ} \mathrm{C}$ in a $5 \% \mathrm{CO}_{2}$ atmosphere in Ham's F-12 medium supplemented with $10 \%$ fetal bovine serum (Gibco BRL, Rockville, MD). Near confluence, cells were removed with trypsin-EDTA, seeded at a density of $2.0 \times 10^{4}$ cells/well into 96-well plates in the same medium supplemented with $10 \%$ of charcoal-treated FBS and incubated for $24 \mathrm{~h}$ at $37{ }^{\circ} \mathrm{C}, 5 \% \mathrm{CO}_{2}$. Using Fugene 6 (Roche) or lipofectamine (GIBCO) as the transfection reagent according to the manufacturer's instruction with some modification, cells were cotransfected with appropriate amounts of $\mathrm{pBK}-\mathrm{CMV}-\mathrm{Ga} 4-\mathrm{hER} \alpha$ (or $\beta$ ) and $\mathrm{pBK}-\mathrm{CMV}$ (UAS) ${ }_{4}$-tk-alkaline phosphatase (AP) in $100 \mu \mathrm{L}$ of serum-free Ham's F-12 medium containing the appropriate amount of the transfection reagent. After $5 \mathrm{~h}$, cells were treated with Ham's F-12 medium containing $10 \%$ serum replacement (TCM) (Celox, St. Paul, MN) and vehicle (ethanol or DMSO), $17 \beta$-estradiol $\left(\mathrm{E}_{2}\right)$ or test samples in appropriate concentrations. Test samples dissolved in a minimal volume of vehicle were diluted to appropriate concentrations with Ham's F-12 medium containing $10 \%$ serum replacement immediately before use. After $48 \mathrm{~h}, 50 \mu \mathrm{L}$ of culture medium was transferred to a new 96-well plate for the reporter gene (activity of alkaline phosphatase, AP) assay. As previously described, an equal volume of SEAP assay solution containing $20 \mathrm{mM}$ p-nitrophenyl phosphate (pNPP), $1 \mathrm{mM} \mathrm{MgCl}_{2}, 10$ $\mathrm{mM}$ L-homoarginine, and $1 \mathrm{M}$ diethanolamine, $\mathrm{pH} 9.8$, was added and mixed (14). Absorbance was read at $405 \mathrm{~nm}$ at $15 \mathrm{~min}$. Fold of activation was calculated by taking the AP activity of vehicle-treated cells as 1 . Cell viability was examined using the MTT assay. Data of transactivation obtained were considered valid only in experiments in which sample treatment did not alter cell growth and viability.

Extractions. Lyophilized powders of yam samples were extracted with 30-fold $(\mathrm{w} / \mathrm{v})$ methanol $(\mathrm{MeOH})$, ethyl acetate (EtOAc), or $n$-hexane (hexane), respectively, for $24 \mathrm{~h}$. The extracts were evaporated in a rotary evaporator to remove the solvent, and the residue of $\mathrm{MeOH}$, EtOAc, or hexane extracts was obtained.

Fractionation, Isolation, and Identification of Active Compounds. Eighteen kilograms of lyophilized powder of the TNG2 yam was extracted with 10-fold (w/v) ethyl acetate (EtOAc). The extract was evaporated in a rotary evaporator to remove the solvent, and the residual extract (EAE) was obtained. The EAE was further separated by silica gel column chromatography eluted by increasing the proportion of ethyl acetate in $n$-hexane. Fractions obtained were tested for estrogenic activity using the transactivation assay. The isolated active compounds were identified by NMR and mass spectrometry to elucidate the chemical structures. ${ }^{1} \mathrm{H}$ and ${ }^{13} \mathrm{C}$ NMR spectra were run on a Bruker Avance-500 MHz FT NMR, and ESI-MS and EI-MS data were obtained on a Finnigan TSQ 700 mass spectrometer.

Three fractions were obtained in 5-10\% EtOAc/hexane eluate. The first fraction $(732 \mathrm{mg}$ ) was subjected to a second silica gel column chromatography, eluted by $2 \%$ ethyl acetate/ $98 \% n$-hexane. The active fraction obtained was further separated by preparative HPLC, and $10 \%$ EtOAc/90\% $n$-hexane was used as a mobile phase. Finally elution with $2 \%$ EtOAc, $1 \%$ methanol, $87 \% n$-hexane, and $10 \%$ chloroform $\left(\mathrm{CHCl}_{3}\right)$ yielded $R R R$ - $\alpha$-tocopherol $(18.3 \mathrm{mg})(15)$ and elutionwith $10 \%$ EtOAc/ 90\% $n$-hexane yielded compound 1 (5 mg).

The second fraction $(80 \mathrm{mg})$ of $5-10 \%$ EtOAc/hexane eluate was separated by preparative HPLC. The mobile phase was a mixture of $2 \%$ EtOAc, $1 \%$ methanol, $87 \% n$-hexane, and $10 \%$ chloroform $\left(\mathrm{CHCl}_{3}\right)$, and the flow rate was $2 \mathrm{~mL} / \mathrm{min}$. The fraction eluted at a period between 8.5 and 9.3 min was collected and further analyzed by NMR. The chemical structure was identified as coenzyme $\mathrm{Q}_{9}(31.4 \mathrm{mg})$ (16). The fraction eluted at a period 12.6 to $14.7 \mathrm{~min}$ was further purified by a second HPLC. The mobile phase was $12 \%$ EtOAc/88\% $n$-hexane with a flow rate of $3 \mathrm{~mL} / \mathrm{min}$. In the fraction eluted at a period between 8.5 to $9.5 \mathrm{~min}$, compound $2(7.5 \mathrm{mg})$ was obtained as an amorphous solid.

The third fraction $(34 \mathrm{mg}$ ) of 5-10\% EtOAc/hexane eluate was purified by preparative HPLC. The mobile phase was $10 \%$ EtOAc/ $90 \% n$-hexane, and the flow rate was $4.5 \mathrm{~mL} / \mathrm{min}$. The fraction eluted at a period between 8.2 and 9.1 min was collected and identified as cycloartane $(32.7 \mathrm{mg})(17)$.

The 50\% EtOAc/hexane fraction obtained from silica gel chromatography was purified by preparative HPLC. The mobile phase was a mixture of $2 \%$ EtOAc, $2 \%$ methanol, and $96 \%$ dichloromethane, and the flow rate was $3 \mathrm{~mL} / \mathrm{min}$. The fraction eluted at a period between 10.0 and 11.5 min was collected and identified as 1 -feruloylglycerol (12.8 mg) (18).

Data Analysis. Data reported were expressed as means \pm standard deviation of at least three separate experiments with triplicate wells in each. The significance of difference between each treatment was analyzed by one-way ANOVA (analysis of variance) or Student's $t$ test using SAS (SAS 8.1, Cary, NC) software.

\section{RESULTS}

Validation of the Estrogenic Activity Assay. Endogenous estrogen, $17 \beta$-estradiol $\left(\mathrm{E}_{2}\right)$, and three well-known phytoestrogen isoflavones all dose-dependently increased AP activity in our transactivation assay (data not shown). The $\mathrm{EC}_{50}$ of genistein, daidzein, and genistin for $\mathrm{hER} \alpha$ were 299,875 , and $726 \mathrm{nM}$, respectively. The $\mathrm{EC}_{50}$ for $\mathrm{hER} \beta$ were $3.4,52.4$, and $13.9 \mathrm{nM}$, respectively. Our transactivation assay is thus validated since these data clearly demonstrate that genistein was most potent among the three isoflavones and all three showed high selectivity to $\mathrm{hER} \beta$, consistent with the well-known characteristic of these phytoestrogenic isoflavones. $1 \mathrm{nM} 17 \beta$-estradiol $\left(E_{2}\right)$ was used as a positive control in the following experiments.

The Estrogenic Activity of Yam. Ethyl acetate extracts of all seven species/varieties of yam showed significant ER activity 

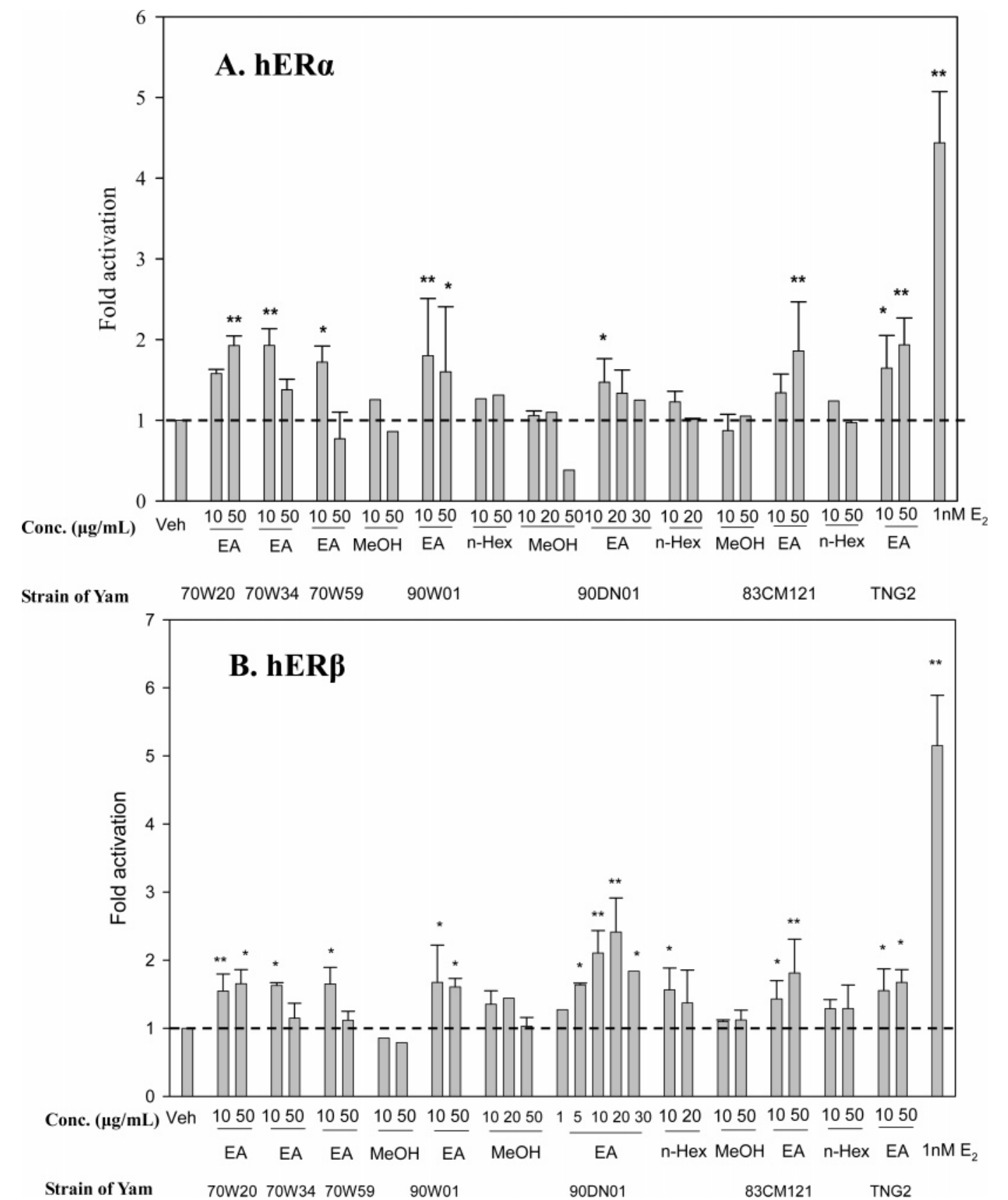

Figure 1. Transactivation of $(\mathbf{A}) \mathrm{hER} \alpha$ and (B) hER $\beta$ by extracts of yam. Lyophilized powder of seven species/varieties (70W20, 70W34, 70W59, 90W01, 90DN01, 83CM121, TNG2) of yam was extracted with methanol (MeOH), ethyl acetate (EA), or $n$-hexane ( $n$-Hex) and tested for ER activities using the transactivation assay as described in the text. Values are means \pm SD $(n=3-9)$. * and ${ }^{* *}$ denote significantly different from vehicle (Veh) at $p<0.05\left(^{*}\right)$ or $p<0.01\left(^{* *}\right)$ analyzed by Student's $t$ test.

in the transactivation assay (Figure 1). At a concentration of $10 \mu \mathrm{g} / \mathrm{mL}$, EtOAc extracts of five species/varieties (70W20, 70W34, 90W01, 83CM121, and TNG2) showed significant activation of hER $\alpha$ that was more than $20 \%$ that of $1 \mathrm{nM}$ of $17 \beta$-estradiol (Figure 1A). A similar concentration of EtOAc extract of six strains (70W20, 70W34, 90W01, 90DN01, 83CM121, and TNG2) showed significant activation of hER $\beta$ that was more than $15 \%$ that of $1 \mathrm{nM}$ of $17 \beta$-estradiol (Figure 1B). Although the extraction yield was highest with methanol, the methanol extract of all species/varieties activated neither $\mathrm{hER} \alpha$ nor $\mathrm{hER} \beta$. The $n$-hexane extract had no ER activity either.

Identification of Active Compounds in the Yam EtOAc Extract (EAE). TNG2 (D. alata) powder was extracted with EtOAc with an extraction yield of about $0.34 \%$. The EAE was separated by silica gel chromatography eluting with increasing proportion of EtOAc in $n$-hexane. Six fractions were obtained and tested for their estrogenic activity using the transactivation assay. As shown in Figure 2, EAE fractions eluted by $2 \%$, $5-10 \%$, and $20 \%$ EtOAc/hexane showed significant activation on $\mathrm{hER} \alpha$ and $\beta$. In addition, the $50 \%$ fraction showed activation on $\mathrm{hER} \beta$ but not hER $\alpha$.

Based on the ${ }^{1} \mathrm{H}$ NMR, ${ }^{13} \mathrm{C}$ NMR, NOESY, and HMBC spectra, compound $\mathbf{1}$ was identified as hydro- $\mathrm{Q}_{9}$ chromene (Figure 3A), a derivative of coenzyme $\mathrm{Q}_{9}$. It is a light yellow amorphous solid, $\mathrm{C}_{54} \mathrm{H}_{82} \mathrm{O}_{4},[\alpha]_{\mathrm{D}}^{29}=-8.52$ ( $c=0.04$, chloroform), UV (hexane) $\lambda_{\max } \mathrm{nm} 232,275,330 ; \mathrm{ESI}^{+} \mathrm{MS}, \mathrm{m} / z$ 795.3 $[\mathrm{M}+1]^{+}(84 \%), 794.5(100 \%), 793.6(67 \%), 792.4(17 \%)$, $791.4(8 \%), 621$ (3\%). The ${ }^{1} \mathrm{H}$ NMR spectrum (Table 1) indicated the presence of olefinic protons $[\delta 6.48(1 \mathrm{H}, d, J=$ $10.1 \mathrm{~Hz}), \delta 5.56(1 \mathrm{H}, d, J=10.1 \mathrm{~Hz})$, and $\delta 5.09(8 \mathrm{H}, m)]$. It 


\section{A. hERa}

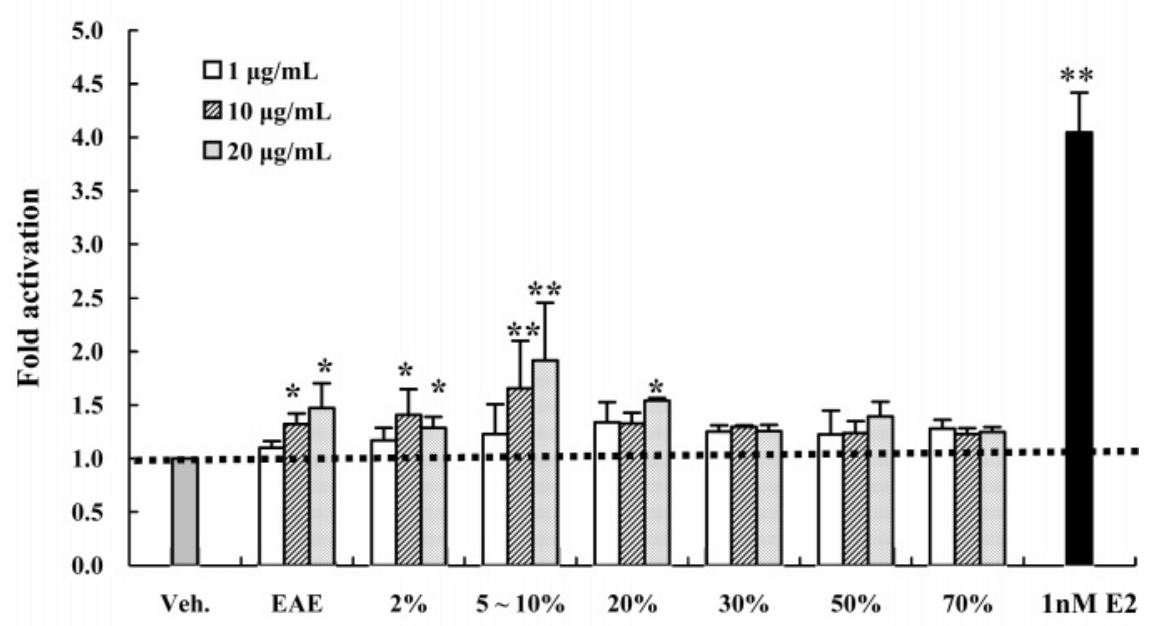

$\%$ of Ethyl acetate in $n$-Hexane

\section{B. hERß}

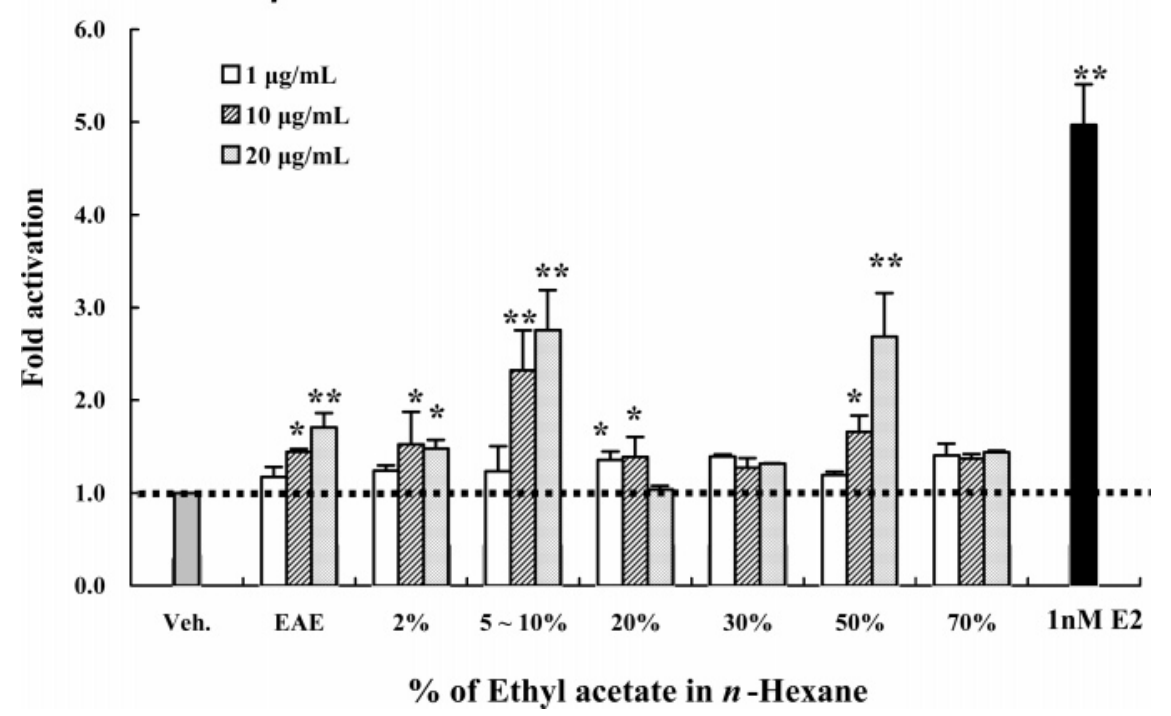

Figure 2. Transactivation of $(\mathbf{A}) \mathrm{hER} \alpha$ and $(\mathbf{B}) \mathrm{hER} \beta$ by various fractions eluted from silica gel column chromatography of TNG2 EA extract. Values are means \pm SD of triplicate wells in a representative experiment. Data shown are representative of at least three separate experiments with similar results. $17 \beta$-Estradiol $(1 \mathrm{nM})$ is the positive control. * and ${ }^{* *}$ denote significantly different from vehicle at $p<0.05\left(^{*}\right)$ or $p<0.0001\left(^{* *}\right)$ analyzed by Student's $t$ test. Vehicle (Veh.) contains $1 \%$ ethanol, and EAE is the EA extract of TNG2.

also showed two methoxy signals $[\delta 3.92(3 \mathrm{H}, s)$ and $\delta 3.86$ $(3 \mathrm{H}, s)]$ and a methyl group attached to an aromatic ring $[\delta$ $2.14(3 \mathrm{H}, s)]$. The signal at $\delta 1.58(3 \mathrm{H} \times 7, s)$ was assigned to the methyl protons of an internal $(E)$-prenyl residue. The signals at $\delta 1.66(3 \mathrm{H}, s)$ and $\delta 1.57(3 \mathrm{H}, s)$ were the methyl protons of an $\omega$-end prenyl residue. The signal at $\delta 1.36(3 \mathrm{H}, s)$ was assigned to the methyl protons of oxygenated carbon (C-2). The ${ }^{13} \mathrm{C}$ NMR spectrum showed a chromene signal and a methyl group, and two methoxy groups attached to the aromatic ring. The signals at $\delta 39.7$ and $\delta 16.0$ were ascribed to an $E$-configuration (19). The HMBC spectrum of hydro- ${ }_{9}$ chromene exhibited the key correlations between $\mathrm{C} 5-\mathrm{Me}$ and $\mathrm{C}-4 \mathrm{a}$ and C-6. The NOESY correlation between $\delta 2.14$ and $\delta 6.48$ afforded the evidence that $\delta 2.14$ is assigned as C5-Me (Figure 3B). The new hydro- $Q_{9}$ chromene can be elucidated as shown in the structure based on the above ${ }^{1} \mathrm{H}$ and ${ }^{13} \mathrm{C}$ NMR and 2D techniques, spectral illustrations, and the MS spectrum.

Compound $\mathbf{1}$ dose-dependently activated both forms of ER in the transactivation assay (Figure 4). At a concentration of $40 \mu \mathrm{g} / \mathrm{mL}(50.3 \mu \mathrm{M})$, hydro-Q9 chromene activated $\mathrm{hER} \alpha$ and
$\mathrm{hER} \beta$ to maximal folds of activation that were $77 \%$ and $102 \%$ that of $1 \mathrm{nM} \mathrm{E}$. The $\mathrm{EC}_{50}$ value for $\mathrm{hER} \alpha$ was $8.54 \mu \mathrm{g} / \mathrm{mL}$ $(10.8 \mu \mathrm{M})$ and for $\mathrm{hER} \beta$ was $5.85 \mu \mathrm{g} / \mathrm{mL}(7.4 \mu \mathrm{M})$.

Compound 2 was identified as $\gamma$-tocopherol-9 (Figure 5A). It is a light yellow amorphous solid, $\mathrm{C}_{53} \mathrm{H}_{82} \mathrm{O}_{2},[\alpha]_{\mathrm{D}}^{29}=-5.41$ ( $c=0.23$, chloroform); EIMS, $m / z 750.9$ (19\%), $410.4(5 \%)$, 341.4 (10\%), 267.2 (5\%), 203.2 (10\%), 191.1 (39\%), 189.1 (60\%), $151.1(100 \%), 81.1$ (28\%), 69.1 (34\%). The ${ }^{1} \mathrm{H}$ NMR and ${ }^{13} \mathrm{C}$ NMR data of $\gamma$-tocopherol-9 are shown in Table 2. The ${ }^{1} \mathrm{H}$ NMR spectrum (Table 2) indicated the presence a phenyl proton $[\delta 6.38(1 \mathrm{H}, s)]$, two phenyl methyl groups $[\delta$ $2.13,2.14(3 \mathrm{H}$ each, $s)]$, and a phenolic proton $[\delta 4.20 \mathrm{brs}]$ exchangeable with $\mathrm{D}_{2} \mathrm{O}$. It also showed benzylic methylene $2 \mathrm{H}$ protons $[\delta 2.68(2 \mathrm{H}, m)]$ that coupled with two methylene protons $[\delta 1.72(1 \mathrm{H}, m)$ and $1.81(1 \mathrm{H}, m)]$ assigned as Ha-3, $\mathrm{Hb}-3$. The signal at $\delta 1.61(3 \mathrm{H} \times 7, s)$ was assigned to the methyl protons of an internal $(E)$-prenyl residue. The signals at $\delta 1.69(3 \mathrm{H}, s)$ and $\delta 1.61(3 \mathrm{H}, s)$ were the methyl protons of an $\omega$-end prenyl residue. The signal at $\delta 1.26(3 \mathrm{H}, s)$ was 
(A)<smiles>COCCCCCC(C)=CCCC=C(C)C</smiles>

(B)

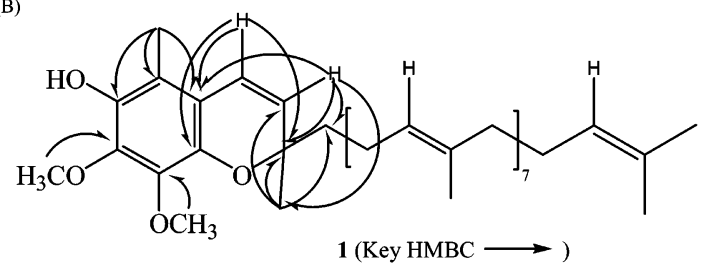

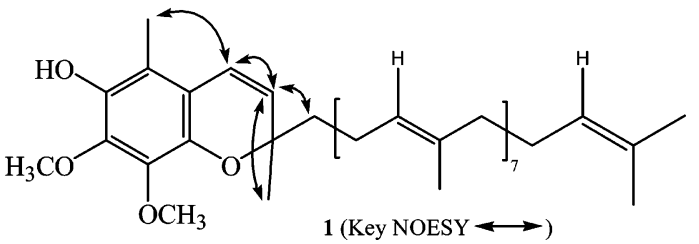

Figure 3. (A) Structure of the new compound hydro- $Q_{9}$ chromene isolated from TNG2 EtOAc extract. (B) The correlations of HMBC and NOESY in hydro-Qg chromene.

Table 1. ${ }^{13} \mathrm{C}$ NMR and ${ }^{1} \mathrm{H}$ NMR Spectroscopic Data for Hydro- $\mathrm{Q}_{9}$ Chromene (1) (500 MHz, $125 \mathrm{MHz}$ in $\mathrm{CDCl}_{3}$ )

\begin{tabular}{|c|c|c|}
\hline no. & $\delta_{\mathrm{C}}$ & $\delta_{\mathrm{H}}$ \\
\hline 1 & & \\
\hline 2 & 77.2 & \\
\hline 3 & 129.0 & $5.56(1 \mathrm{H}, \mathrm{d}, J=10.1 \mathrm{~Hz})$ \\
\hline 4 & 119.8 & $6.48(1 \mathrm{H}, \mathrm{d}, J=10.1 \mathrm{~Hz})$ \\
\hline $4 a$ & 116.4 & \\
\hline 5 & 113.9 & \\
\hline 6 & 140.4 & \\
\hline 7 & 139.5 & \\
\hline 8 & 138.9 & \\
\hline $8 a$ & 139.5 & \\
\hline 9 & 40.8 & $\begin{array}{l}1.78(1 \mathrm{H}, \mathrm{ddd}, J=14.0,11.0,6.0 \mathrm{~Hz}) \\
1.66(1 \mathrm{H}, \mathrm{m})\end{array}$ \\
\hline $\mathrm{C} 2-\mathrm{Me}$ & 25.5 & $1.36(3 \mathrm{H}, \mathrm{s})$ \\
\hline $\mathrm{C} 5-\mathrm{Me}$ & 10.3 & $2.14(3 \mathrm{H}, \mathrm{s})$ \\
\hline C7-OMe & 61.4 & $3.92(3 \mathrm{H}, \mathrm{s})$ \\
\hline C8-OMe & 61.0 & $3.86(3 \mathrm{H}, \mathrm{s})$ \\
\hline $1 E$ & $26.7 \times 7$ & $2.04(14 \mathrm{H}, \mathrm{m})$ \\
\hline $2 E$ & $124.3 \times 7$ & $5.09(7 \mathrm{H}, \mathrm{m})$ \\
\hline $3 E$ & $134.9 \times 7$ & \\
\hline $4 E$ & $39.7 \times 7$ & $1.96(14 \mathrm{H}, \mathrm{m})$ \\
\hline $5 E$ & $16.0 \times 7$ & $1.58(21 \mathrm{H}, \mathrm{s})$ \\
\hline $1 \omega$ & 26.7 & $2.04(2 \mathrm{H}, \mathrm{m})$ \\
\hline $2 \omega$ & 124.2 & $5.09(1 \mathrm{H}, \mathrm{m})$ \\
\hline $3 \omega$ & 131.0 & \\
\hline $4 \omega$ & 25.7 & $1.57(3 \mathrm{H}, \mathrm{s})$ \\
\hline $5 \omega$ & 17.7 & $1.66(3 \mathrm{H}, \mathrm{s})$ \\
\hline$-\mathrm{OH}$ & & 5.40 \\
\hline
\end{tabular}

assigned to the methyl group attached on the oxygenated carbon (C-2). The main structure was consistent with $\gamma$-tocopherol, but had a longer phytyl side chain. The key HMBC and NOESY correlations are presented in Figure 5B. By combination of the above spectra and MS spectral data, the structure of the new compound $\gamma$-tocopherol- 9 was elucidated as the shown structure.

As shown in Figure 6, $\gamma$-tocopherol-9 dose-dependently activated $\mathrm{hER} \alpha$ and $\mathrm{hER} \beta$. At a concentration of $20 \mu \mathrm{g} / \mathrm{mL}$ (26.6 $\mu \mathrm{M})$, the maximal activation of the $\operatorname{hER} \alpha$ and $\operatorname{hER} \beta$ was achieved (77\% and $84 \%$ that of $1 \mathrm{nM} \mathrm{E}_{2}$ ). The $\mathrm{EC}_{50}$ values for $\mathrm{hER} \alpha$ and $\mathrm{hER} \beta$ were $9.56 \mu \mathrm{g} / \mathrm{mL}(12.7 \mu \mathrm{M})$ and $2.40 \mu \mathrm{g} / \mathrm{mL}$ (3.2 $\mu \mathrm{M})$, respectively.
Four known compounds were also isolated from active fractions collected from silica gel chromatography of TNG2 EAE. Among the four compounds, $R R R$ - $\alpha$-tocopherol showed the highest maximal fold of activation. As shown in Figure 7A, $R R R$ - $\alpha$-tocopherol dose-dependently activated $\mathrm{hER} \alpha$ and $\mathrm{hER} \beta$. The maximal activation of $\mathrm{hER} \alpha$ and $\mathrm{hER} \beta$ was observed at concentrations of $5 \mu \mathrm{g} / \mathrm{mL}(11.6 \mu \mathrm{M})$ and $20 \mu \mathrm{g} / \mathrm{mL}(26.5$ $\mu \mathrm{M})$, respectively. The $\mathrm{EC}_{50}$ values for $\mathrm{hER} \alpha$ and $\mathrm{hER} \beta$ were $1.08 \mu \mathrm{g} / \mathrm{mL}(2.5 \mu \mathrm{M})$ and $3.96 \mu \mathrm{g} / \mathrm{mL}(9.2 \mu \mathrm{M})$, respectively. Coenzyme $\mathrm{Q}_{9}$ also activated $\mathrm{ER} \alpha$ and $\mathrm{ER} \beta$ in a dose-dependent manner (Figure 7C). The maximal activation of both ER $\alpha$ and $\mathrm{ER} \beta$ by coenzyme $\mathrm{Q}_{9}$ was observed at $20 \mu \mathrm{g} / \mathrm{mL}(25.2 \mu \mathrm{M})$. At this concentration, the fold of activation for $\mathrm{hER} \alpha$ and $\mathrm{hER} \beta$ was 77 and $27 \%$ that of $1 \mathrm{nME}_{2}$. The $\mathrm{EC}_{50}$ for $\mathrm{hER} \alpha$ and $\mathrm{hER} \beta$ was $40.5 \mu \mathrm{g} / \mathrm{mL}(13.3 \mu \mathrm{M})$ and $0.8 \mu \mathrm{g} / \mathrm{mL}(1.1 \mu \mathrm{M})$, respectively. At a concentration of $149 \mu \mathrm{M}, 1$-feruloylglycerol activated $\mathrm{hER} \beta$ to a maximal extent that was equivalent to $72 \%$ that activated by $1 \mathrm{nM} \mathrm{E} E_{2}$. In contrast, this compound activated $\mathrm{hER} \alpha$ only very slightly (Figure 7D). The $\mathrm{EC}_{50}$ of $\mathrm{hER} \beta$ is $20.1 \mu \mathrm{M}$. 1-Feruloylglycerol thus appears to be more selective to $\operatorname{hER} \beta$ in contrast to $R R R$ - $\alpha$-tocopherol that appeared to be more selective to $\mathrm{hER} \alpha$. Compared to the above-mentioned three compounds, cycloartane showed very limited activity (Figure 7B).

\section{DISCUSSION}

The transactivation assay using cotransfecting $\mathrm{CHO}$ cells with vectors containing GAL4-ER LBD chimeric receptor and UASAP reporter has been extensively used to screen and identify nuclear receptor ligands. Compared to the original system that cotransfected with full length ER cDNA and reporter gene downstream of an ERE, this assay limits the interference from endogenous DNA binding protein and other nuclear receptors that can bind to estrogen response element (ERE) (20).

Most of the known phytoestrogens, such as isoflavones, coumestans, and lignans, are relatively polar compounds and can be extracted by methanol. Surprisingly, the estrogenic activity of yam could not be detected in the methanol extract but could be detected in the ethyl acetate extract (Figure 1). This implied that active compounds in yam might be different from those well-known classes of phytoestrogens.

Although the yam 90DN01 showed highest ER activation among the seven species/varieties of yam tested, it was not chosen as the material for active compound isolation and identification since this species is not for common food use and is not routinely cultivated in Taiwan. In addition, the EtOAc extract of 90DN01 yam showed higher cytotoxicity in the MTT cell viability assay. As EtOAc extracts of all seven species/ varieties of yam showed ER activity, it is presumable that a similar pattern of active estrogenic compounds exists in all seven species/varieties of yam but with different content and proportion. TNG2 was chosen as the sample material for active compound isolation because of its popularity and low price.

Diosgenin (3- $\beta$-hydroxy-5-spirostene) is the primary furostanol saponin found in several plants, including Dioscorea species (21). Diosgenin obtained by hydrolysis of yam saponin has been a principal raw material for the industrial production of steroid drug, including estrogen (22). In our transactivation assay, however, commercially available pure diosgenin showed no ER activity (data not shown).

Among the estrogenic compounds isolated from yam in this study, only 1-feruloylglycerol has a structure with two hydroxyl groups located at opposite ends of the molecule, similar to isoflavone, that are regarded as possessing a structural similarity 


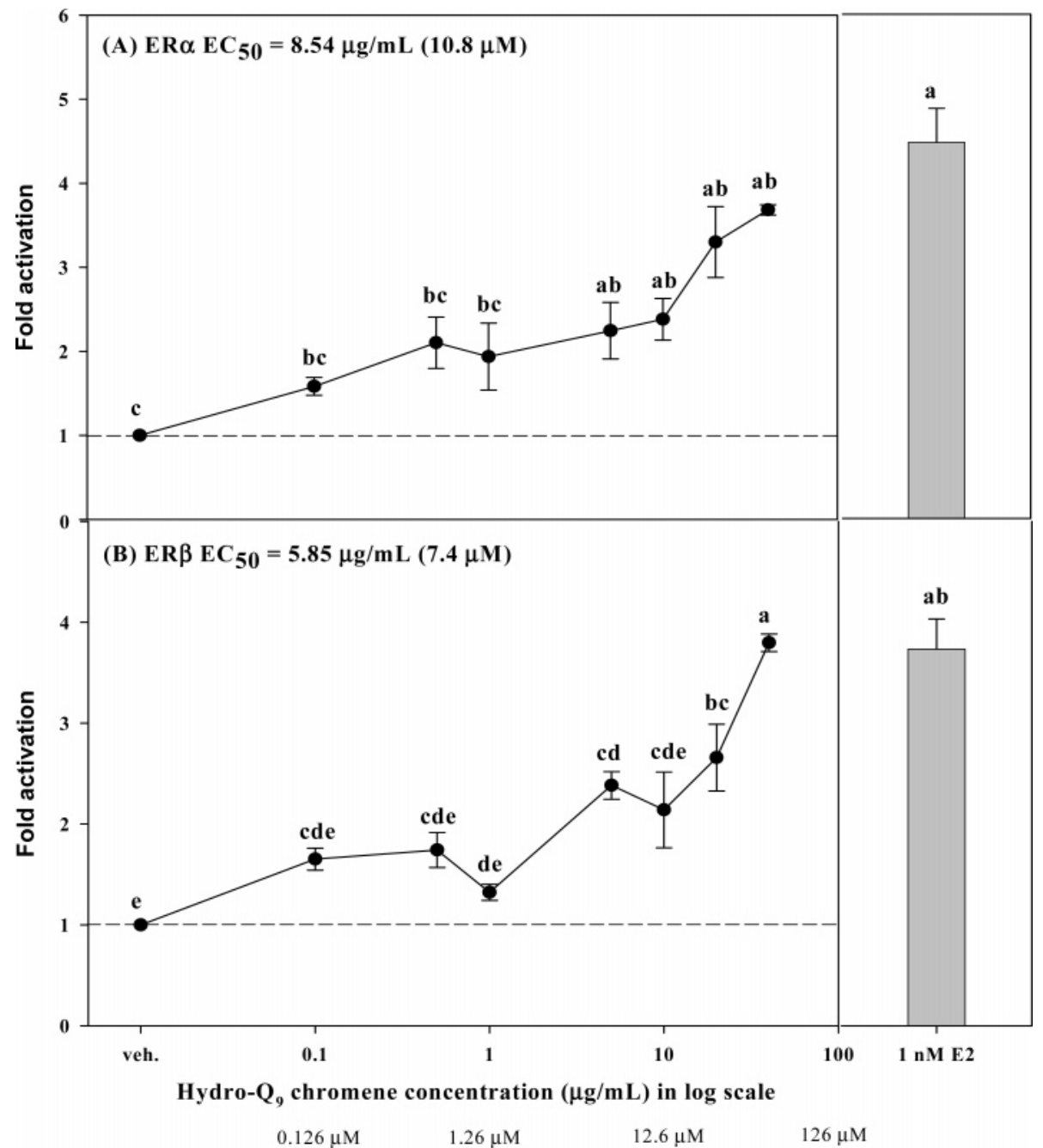

Figure 4. Dose response curves for the transactivation of $(\mathbf{A}) \mathrm{hER} \alpha$ and $(\mathbf{B}) \mathrm{hER} \beta$ by hydro- $\mathrm{Q}_{9}$ chromene. Values are means $\pm \mathrm{SD}$ of triplicate wells in a representative experiment. Data shown are representative of at least three separate experiments with similar results. $17 \beta$-Estradiol $(1 \mathrm{nM})$ is the positive control. Values not sharing the same letter are significantly different from one another by one-way ANOVA $(p<0.05)$.

with endogeneous estrogen. Noticeably, 1-feruloylglycerol has only one ring in the structure that is distinct from other known phytoestrogens. Interestingly, ferulic acid is a marker compound of a few herbs that are considered to be beneficial for postmenopausal women, such as black cohosh (23) and dong quai (24). More importantly, 1-feruloylglycerol showed highest selectivity to $\mathrm{hER} \beta$ among the estrogenic compounds identified in this study.

Four active compounds isolated from yam in this study, namely, $R R R$ - $\alpha$-tocopherol, $\gamma$-tocopherol 9, hydro- ${ }_{9}$ chromene, and coenzyme $\mathrm{Q}_{9}$, possess a ring system and a phytyl side chain. The presence of a phenolic hydroxyl group is in common with the known phytoestrogens. These four compounds are thus wellknown ( $\tilde{\alpha}$-tocopherol and $\mathrm{CoQ}_{9}$ ) or can be predicted to have good antioxidant activity. This is also in common with the wellknown phytoestrogens. Recently, resveratrol (25), ellagic acid (26) and nordihydroguaiaretic acid (NDGA) (27), have been demonstrated to have estrogenic activity. These latter three compounds also possess phenolic hydroxyl groups and are wellknown for their antioxidant activity. It is speculated that phenolic hydroxyl group might be important in the binding with estrogen receptor.

Coenzyme Q (CoQ) is an unusual lipid, and the structure is characterized by the redox active benzoquinone ring linked to a long isoprenoid side chain. It is present in all cells and plays an important role in the mitochondrial respiratory chain.
(A)<smiles>CC(C)=CCCC(C)=CCCC1(C)CCc2cc(O)c(C)c(C)c2O1</smiles>

(B)

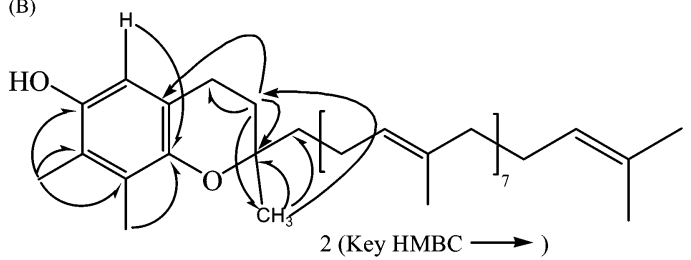<smiles>CCCC1(C)Oc2c(C)c(C)c(O)c3c2C2(CCCCC32CC)[Te]1</smiles>

Figure 5. (A) Structure of the new compound $\gamma$-tocopherol-9 isolated from TNG2 EA extract. (B) The correlations of HMBC and NOESY in $\gamma$-tocopherol-9. 
Table 2. ${ }^{13} \mathrm{C}$ NMR and ${ }^{1} \mathrm{H}$ NMR Spectroscopic Data for $\gamma$-Tocopherol-9 (2) $\left(500 \mathrm{MHz}, 125 \mathrm{MHz}\right.$ in $\left.\mathrm{CDCl}_{3}\right)$

\begin{tabular}{llllll}
\multicolumn{1}{c}{ no. } & $\delta_{\mathrm{C}}$ & \multicolumn{1}{c}{$\delta_{\mathrm{H}}$} & \multicolumn{1}{c}{ no. } & \multicolumn{1}{c}{$\delta_{\mathrm{C}}$} & \multicolumn{1}{c}{$\delta_{\mathrm{H}}$} \\
\hline 1 & & & $\mathrm{C} 7-\mathrm{Me}$ & 11.9 & $2.14(3 \mathrm{H}, \mathrm{s})$ \\
2 & 75.2 & & $\mathrm{C}-\mathrm{Me}$ & 11.8 & $2.13(3 \mathrm{H}, \mathrm{s})$ \\
3 & 31.4 & $1.72(1 \mathrm{H}, \mathrm{m})$ & $1 E$ & $26.6 \times 7$ & $2.08(14 \mathrm{H}, \mathrm{m})$ \\
& & $1.81(1 \mathrm{H}, \mathrm{m})$ & $2 E$ & $124.3 \times 7$ & $5.13(7 \mathrm{H}, \mathrm{m})$ \\
4 & 22.3 & $2.68(2 \mathrm{H}, \mathrm{m})$ & $3 E$ & $134.9 \times 7$ & \\
$4 \mathrm{a}$ & 118.2 & & $4 E$ & $39.7 \times 7$ & $1.99(14 \mathrm{H}, \mathrm{m})$ \\
5 & 112.1 & $6.38(1 \mathrm{H}, \mathrm{s})$ & $5 E$ & $16.0 \times 7$ & $1.61(21 \mathrm{H}, \mathrm{s})$ \\
6 & 146.2 & & $1 \omega$ & 26.6 & $2.08(2 \mathrm{H}, \mathrm{m})$ \\
7 & 125.8 & & $2 \omega$ & 124.3 & $5.13(1 \mathrm{H}, \mathrm{m})$ \\
8 & 121.6 & & $3 \omega$ & 131.0 & \\
$8 \mathrm{a}$ & 145.8 & & $4 \omega$ & 25.7 & $1.61(3 \mathrm{H}, \mathrm{s})$ \\
9 & 39.7 & $1.99(2 \mathrm{H}, \mathrm{m})$ & $5 \omega$ & 17.7 & $1.69(3 \mathrm{H}, \mathrm{s})$ \\
C2-Me & 24.0 & $1.26(3 \mathrm{H}, \mathrm{s})$ & $-\mathrm{OH}$ & & 4.20 \\
\hline
\end{tabular}

Commercially available pure $\mathrm{CoQ}_{10}$ showed very low activity in our transactivation assay, indicating that the chain length of the phytyl side chain seems to be important. $\mathrm{CoQ}_{9}$, hydro- $\mathrm{Q}_{9}$ chromene, and $\gamma$-tocopherol-9 identified in this study all have 8-9 isoprenoid units in the side chain, indicating that a side chain of 32-36 alkyl carbon atoms appears to be more appropriate for interaction with estrogen receptors. Interestingly, well-known antiestrogen drugs, such as ICI 164,384 and 182,-
780, have an alkyl side chain. The structure-activity relationship of the alkyl side chain and ER antagonism has been reported in a study in which the side chain structure was chemically modified (28).

The exact role of active compounds found in this study in the body must be further examined in appropriate in vitro as well as in vivo models. Whether an exogenous estrogenic compound acts as an agonist or an antagonist depends on tissues and endogenous estrogen status (29). The breast cancer therapeutic agent tamoxifen and its active metabolite, 4-hydroxy tamoxifen, can bind ER and showed an agonistic effect in a transactivation assay. Tamoxifen is now well-known to be antiestrogenic in breast tissue but estrogenic in the uterus tissue. Isoflavones have been shown to stimulate the growth of estrogen-dependent MCF-7 cells at low concentrations but inhibit cell growth at high concentrations (30). It would be necessary to further characterize those active compounds identified in this study to be estrogenic or antiestrogenic in various tissues and in the body.

One of the most surprising findings in this study is the estrogenic activity of $R R R$ - $\alpha$-tocopherol, the most potent and biologically important isomer of vitamin E. Tocopherol was so named based on its essentiality for the reproduction function in 1920s. The biological activity of vitamin E has been considered

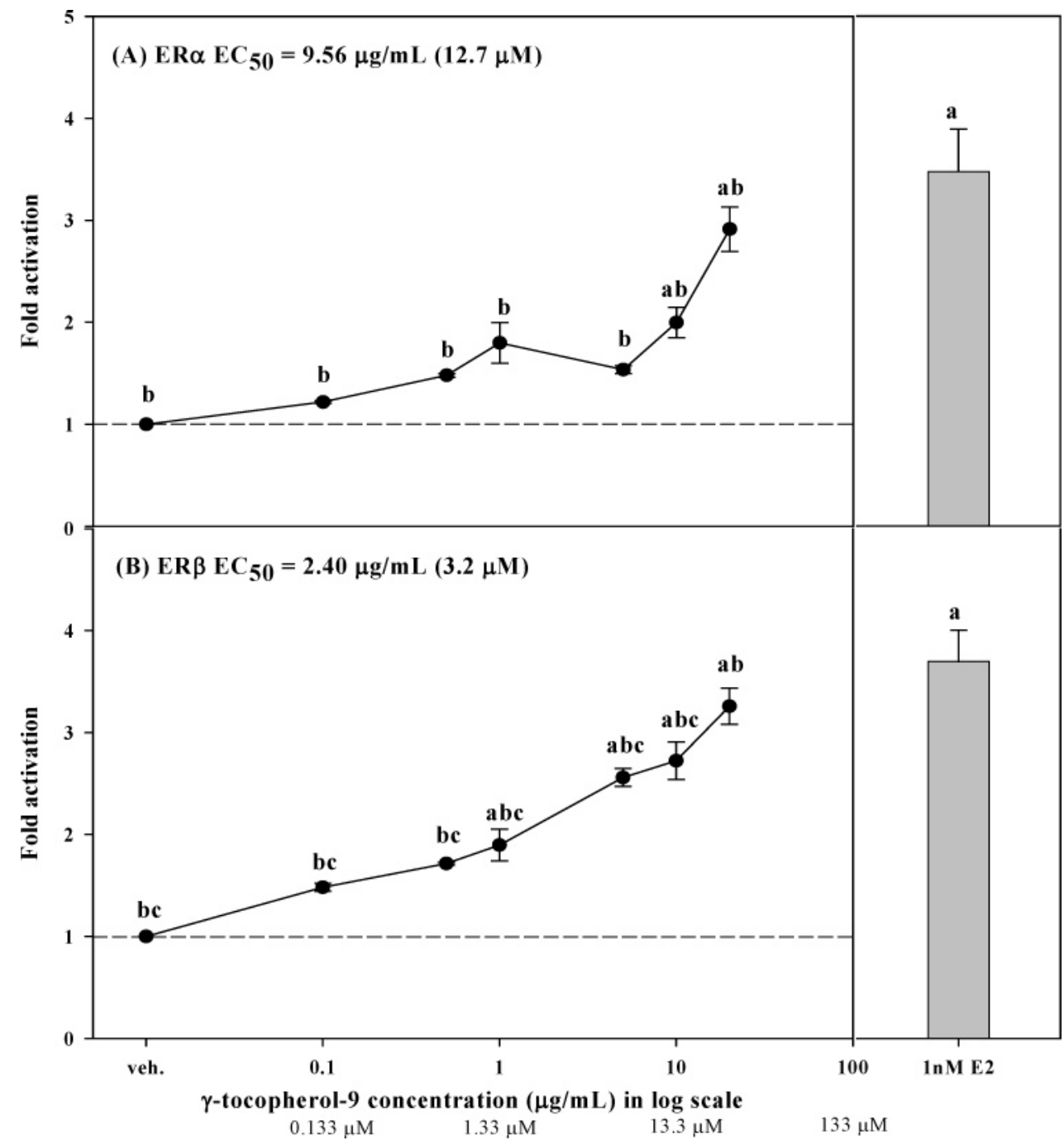

Figure 6. Dose response curves for the transactivation of $(\mathbf{A}) \mathrm{hER} \alpha$ and $(\mathbf{B}) \mathrm{hER} \beta$ by $\gamma$-tocopherol-9. Values are means $\pm \mathrm{SD}$ of triplicate wells in a representative experiment. Data shown are representative of at least three separate experiments with similar results. $17 \beta$-Estradiol (1 nM) is the positive control. Values not sharing the same letter are significantly different from one another by one-way ANOVA $(p<0.05)$. 

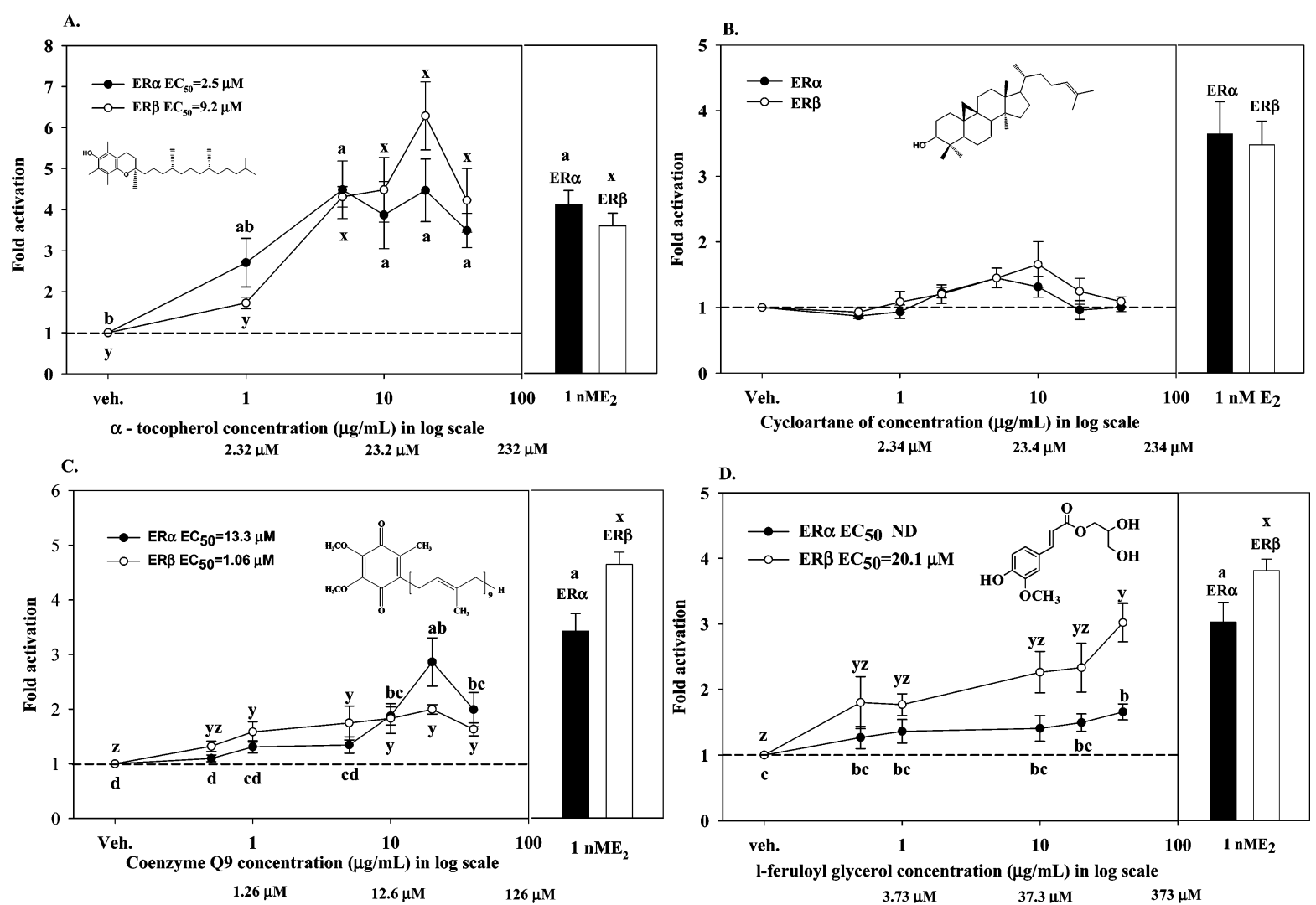

Figure 7. Dose response curves for the transactivation of $h E R \alpha$ and $h E R \beta$ by $(\mathbf{A}) R R R$ - $\alpha$-tocopherol, (B) cycloartane, (C) coenzyme $Q_{9}$, and (D) 1 -feruloylglycerol. Values are means \pm SD of triplicate wells in a representative experiment. Data shown are representative of at least three separate experiments with similar results. $17 \beta$-Estradiol $(1 \mathrm{nM})$ is the positive control. Values not sharing the same letter are significantly different from one another by one-way ANOVA $(p<0.05)$. The meaning of $\mathbf{a}, \mathbf{b}$, and $\mathbf{c}$ represents the existence of significant difference of ER $\alpha$ activities among assayed samples, while $\mathbf{x}, \mathbf{y}$, and $\mathbf{z}$ represent for $\operatorname{ER} \beta$.

as "the most important chain breaking antioxidant in the body". Despite our data showing that $R R R$ - $\alpha$-tocopherol is more potent to $\mathrm{hER} \alpha$ than to $\mathrm{hER} \beta$, Chamras et al. (31) reported that $R R R$ $\alpha$-tocopherol $(100 \mu \mathrm{M})$ has a dose-dependent inhibition of cell proliferation in estrogen-dependent MCF-7 (53\%) and T47D (75\%) cells in the presence of $17 \beta$-estradiol, implying an antagonistic role of this compound in these cells. Again, the estrogenic or antiestrogenic activity for compounds identified in this study needs to be further characterized. Moreover, $\gamma$-tocopherol-9 identified in this study is structurally similar to another isoform of vitamin E, $\gamma$-tocopherol, except that the phytyl side chain is much longer. The physiological significance of the estrogenic activity of vitamin $\mathrm{E}$ in the body is also worthy for further exploration.

The $\mathrm{EC}_{50}$ values of the estrogenic compounds isolated in this study ranged from 2 to $20 \mu \mathrm{M}$, indicating that these compounds are less potent than isoflavones $(3-800 \mathrm{nM}$ in our transactivation assay). Moreover, the yield of EtOAc extraction of lyophilized powder of TNG2 yam is as low as $0.34 \%$, and moisture content of fresh yam flesh is usually at least $70 \%$. This indicates that yam is a very weak estrogenic food. As about $70-80 \%$ of lyophilized yam is carbohydrate, it can be noted that the dose of yam used in the human study of $\mathrm{Wu}$ et al. (5) was replacing two-thirds of the staple foods. It is conceivable that species of yams used as staple food in some tropical countries may have very low content of estrogenic components, since long-term consumption of a large amount of strongly estrogenic active food might have safety concerns for premenopausal women. As for postmenopausal women, a SERM that is protective in cardiovascular disease and osteoporosis but does not increase risks of breast and uterus cancers is preferred.

In conclusion, we purified and identified two new compounds, hydro- $Q_{9}$ chromene and $\gamma$-tocopherol-9, together with four known compounds, $R R R$ - $\alpha$-tocopherol, coenzyme $\mathrm{Q}_{9}$, cycloartane, and 1-feruloylglycerol, from Tainung No. 2 EtOAc extract. Five of them have estrogenic activity based on the liganddependent transcription activation assay. These results provide evidence for the beneficial effect of yam for menopausal women.

\section{ABBREVIATIONS USED}

$\mathrm{E}_{2}, 17 \beta$-estradiol; SEAP, secreted alkaline phosphatase; AP, alkaline phosphatase; hER, human estrogen receptor; TNG 2, Tainung No. 2; EAE, ethyl acetate extract; CoQ, coenzyme Q.

\section{ACKNOWLEDGMENT}

We thank Dr. J. A. Gustaffson, Department of Medical Nutrition, Karolinska Institute, Huddinge, Sweden, for providing vectors and hER $\beta$ cDNA. We thank Dr. S. Y. Liu, Department of Agronomy, Laboratory of Plant Germplasm, Taiwan Agricultural Research Institute, for providing the seven species/ varieties of lyophilized yam samples.

\section{LITERATURE CITED}

(1) Briggs, C. J. Herbal medicine: Dioscorea: The yams-A traditional source of food and drugs. Can. Pharm. J. 1990, 123, $413-415$. 
(2) Liu, S. Y.; Chang, T. W.; Lin, Y. K. Studies on the varietal characters, production potential, phytochemical properties, and antioxidant effect of Dioscorea spp. J. Agric. Res. China 1999, $48,1-22$.

(3) Mirkin, G. Estrogen in yams. JAMA, J. Am. Med. Assoc. 1991, $265,912$.

(4) Russell, L.; Hicks, G. S.; Low, A. K.; Shepherd, J. M.; Brown, C. A. Phytoestrogens: a viable option? Am. J. Med. Sci. 2002, 324, 185-188.

(5) Wu, W. H.; Liu, L. Y.; Chung, C. J.; Jou, H. J.; Wang, T. A. Estrogenic effect of yam ingestion in healthy postmenopausal women. J. Am. Coll. Nutr. 2005, 24, 235-243.

(6) Morito, K.; Hirose, T.; Kinjo, J.; Hirakawa, T.; Okawa, M.; Nohara, T.; Ogawa, S.; Inoue, S.; Muramatsu, M.; Masamune, Y. Interaction of phytoestrogens with estrogen receptors alpha and beta. Biol. Pharm. Bull. 2001, 24, 351-356.

(7) Nilsson, S.; Makela, S.; Treuter, E.; Tujague, M.; Thomsen, J.; Andersson, G.; Enmark, E.; Pettersson, K.; Warner, M.; Gustafsson, J. A. Mechanisms of estrogen action. Physiol. Rev. 2001, $81,1535-1565$.

(8) Middleton, E., Jr.; Kandaswami, C.; Theoharides, T. C. The effects of plant flavonoids on mammalian cells: implications for inflammation, heart disease, and cancer. Pharmacol. Rev. 2000, 52, 673-751.

(9) Kris-Etherton, P. M.; Hecker, K. D.; Bonanome, A.; Coval, S. M.; Binkoski, A. E.; Hilpert, K. F.; Griel, A. E.; Etherton, T. D. Bioactive compounds in foods: their role in the prevention of cardiovascular disease and cancer. Am. J. Med. 2002, 113 (Suppl. 9B), 71S-88S.

(10) Alekel, D. L.; Germain, A. S.; Peterson, C. T.; Hanson, K. B.; Stewart, J. W.; Toda, T. Isoflavone-rich soy protein isolate attenuates bone loss in the lumbar spine of perimenopausal women. Am. J. Clin. Nutr. 2000, 72, 844-852.

(11) Ishida, H.; Uesugi, T.; Hirai, K.; Toda, T.; Nukaya, H.; Yokotsuka, K.; Tsuji, K. Preventive effects of the plant isoflavones, daidzin and genistin, on bone loss in ovariectomized rats fed a calcium-deficient diet. Biol. Pharm. Bull. 1998, 21, 6266.

(12) Boue, S. M.; Wiese, T. E.; Nehls, S.; Burow, M. E.; Elliott, S.; Carter-Wientjes, C. H.; Shih, B. Y.; McLachlan, J. A.; Cleveland, T. E. Evaluation of the estrogenic effects of legume extracts containing phytoestrogens. J. Agric. Food Chem. 2003, 51, 2193-2199.

(13) Chao, C. Y.; Huang, C. J. Bitter gourd (Momordica charantia) extract activates peroxisome proliferator-activated receptors and upregulates the expression of the acyl CoA oxidase gene in H4IIEC3 hepatoma cells. J. Biomed. Sci. 2003, 10, 782-791.

(14) Durocher, Y.; Perret, S.; Thibaudeau, E.; Gaumond, M. H.; Kamen, A.; Stocco, R.; Abramovitz, M. A reporter gene assay for high-throughput screening of G-protein-coupled receptors stably or transiently expressed in HEK293 EBNA cells grown in suspension culture. Anal. Biochem. 2000, 284, 316-326.

(15) Brownstein, S.; Burton, G. W.; Hughes, L.; Ingold, K. U. Chiral effects on the carbon-13 resonances of alpha-tocopherol and related compounds. A novel illustration of Newman's "rule of six”. J. Org. Chem. 1989, 54, 560-569.

(16) Yoshinori, N. Regio- and stereoselective synthesis of coenzymes Qn $(\mathrm{n}=2-10)$, vitamin $\mathrm{K}$, and related polyprenylquinones. $J$. Org. Chem. 1980, 45, 4097-4104.
(17) Choi, Y. H.; Hussain, R. A.; Pezzuto, J. M.; Kinghorn, A. D.; Morton, J. F. Abrusosides A-D, four novel sweet-tasting triterpene glycosides from the leaves of Abrus precatorius. J. Nat. Prod. 1989, 52, 1118-1127.

(18) Hiroko S.; Yutaka S.; Yoshihiro M. Phenolic glycerides from Lilium auratum. Phytochemistry 1987, 26, 844-845.

(19) Aoki, T.; Matsuo, K.; Suga T.; Ohta S. Arachisprenols: Polyprenols possessing a geranyl residue from Arachis hypogaea. Phytochemistry 1997, 46, 715-720.

(20) Schulman, I. G.; Heyman, R. A. The flip side: Identifying small molecule regulators of nuclear receptors. Chem. Biol. 2004, 11, 639-646.

(21) Sautour, M.; Mitaine-Offer, A. C.; Miyamoto, T.; Dongmo, A.; Lacaille-Dubois, M. A. Antifungal steroid saponins from Dioscorea cayenensis. Planta Med. 2004, 70, 90-92.

(22) Chen, Y.; Wu, Y. Progress in research and manufacturing of steroidal sapogenins in China. J. Herbs, Spices Med. Plants 1994, $2,59-70$

(23) Li, W.; Sun, Y.; Liang, W.; Fitzloff, J. F.; van Breemen, R. B. Identification of caffeic acid derivatives in Actea racemosa (Cimicifuga racemosa, black cohosh) by liquid chromatography/ tandem mass spectrometry. Rapid Commun. Mass Spectrom. 2003, 17, 978-982.

(24) Sun, Y.; Li, S.; Song, H.; Tian, S. Extraction of ferulic acid from Angelica sinensis with supercritical CO2. Nat. Prod. Res. 2006, 20, 835-841.

(25) Klinge, C. M.; Risinger, K. E.; Watts, M. B.; Beck, V.; Eder, R.; Jungbauer, A. Estrogenic activity in white and red wine extracts. J. Agric. Food Chem. 2003, 51, 1850-1857.

(26) Papoutsi, Z.; Kassi, E.; Tsiapara, A.; Fokialakis, N.; Chrousos, G. P.; Moutsatsou, P. Evaluation of estrogenic/antiestrogenic activity of ellagic acid via the estrogen receptor subtypes ERalpha and ERbeta. J. Agric. Food Chem. 2005, 53, 7715-7720.

(27) Fujimoto, N.; Kohta, R.; Kitamura, S.; Honda, H. Estrogenic activity of an antioxidant, nordihydroguaiaretic acid (NDGA). Life Sci. 2004, 74, 1417-1425.

(28) Von Angerer, E.; Biberger, C.; Holler, E.; Koop, R.; Leichtl, S. 1-Carbamoylalkyl-2-phenylindoles: relationship between side chain structure and estrogen antagonism. J. Steroid Biochem. Mol. Biol. 1994, 49, 51-62.

(29) McDonnell, D. P.; Connor, C. E.; Wijayaratne, A.; Chang, C. Y.; Norris, J. D. Definition of the molecular and cellular mechanisms underlying the tissue-selective agonist/antagonist activities of selective estrogen receptor modulators. Recent Prog. Horm. Res. 2002, 57, 295-316.

(30) Messina, M. J.; Loprinzi, C. L. Soy for breast cancer survivors: a critical review of the literature. J. Nutr. 2001, 131, 3095S3108 S.

(31) Chamras, H.; Barsky, S. H.; Ardashian, A.; Navasartian, D.; Heber, D.; Glaspy, J. A. Novel interactions of vitamin E and estrogen in breast cancer. Nutr. Cancer 2005, 52, 43-48.

Received for review April 21, 2007. Revised manuscript received June 11, 2007. Accepted June 19, 2007. This study is supported by grants from National Science Council (NSC 92-2321-B-002-011; 93-2321-B002-012; and 94-2321-B-002-008).

JF0711690 